\title{
INTERAKCIÓS SZEMLÉLETÚ HIPNÓZISKUTATÁS: A HIPNÓZIS SZOCIÁL-PSZICHOBIOLÓGIAI MODELLJÉNEK KÍSÉRLETI HÁTTERE
}

\author{
BÁNYAI ÉVA \\ ELTE Eötvös Loránd Tudományegyetem Pszichológiai Intézet \\ E-mail: banyai.eva@ppk.elte.hu \\ Beérkezett: 2018. október 28. - Elfogadva: 2018. december 16.
}

\begin{abstract}
A tanulmány a hipnózis interakciós szemléletū megközelitésének hátterében álló elméleti megfontolások öszszefoglalása után leirja azt a többdimenziós komplex vizsgálati paradigmát, amelyet munkacsoportunk 1982-tól alkalmaz. Párhuzamosan vizsgáljuk a hipnózis-interakció mindkét résztvevôjének - a hipnotizốrnek is - a hipnózis kialakulásában fontos szerepet játszó élettani, magatartási, szubjektív élménybeli és kapcsolati jellemzôit, és elemezzük e tényezók kölcsönhatásait. A vizsgálatok legfontosabb eredményeinek ismertetése után a cikk összefoglalja az ezek alapján kialakitott szociál-pszichobiológiai hipnózis modellt, majd kitér ennek gyakorlati, terápiás jelentôségére és nemzetközi fogadtatására.
\end{abstract}

Kulcsszavak: hipnózis, interakciós szemlélet, szociál-pszichobiológiai modell, interakciós szinkronitás, hipnózisstílus 
Bányai Éva

\section{BEVEZETÉS}

Az általam 1981-ben kezdeményezett interakciós szemléletû hipnóziskutatási paradigmát és az alkalmazásával nyert eredmények részleteit, valamint az ezek alapján megfogalmazott szociál-pszichobiológiai hipnózismodellt több - köztük néhány magyar nyelvú, áttekintô jellegú - közleményben már ismertettük (Bányai, 1985, 1991, 1998, 2000, 2002, 2008, 2015; Bányai, Gôsi-Greguss, Vágó, Varga és Horváth, 1990; Bányai, Mészáros és Csókay, 1985; Varga, 2017; Varga, Bányai és Gôsi-Greguss, 1994; Varga, Bányai, Gôsi-Greguss és Tauszik, 2013; Varga és Kekecs, 2014), ezért itt csak a megközelítéssel nyert legfontosabb eredményeket, és a modell lényeges jellegzetességeit foglalom össze.

\section{Az interakciós megközelités elözményei}

A hipnózissal foglalkozó szakirodalom hagyományosan vagy csak a hipnotizôr „mágikus erejét” és „virtuóz technikáját” hangsúlyozta (mint a modern hipnózis hajnalán F. A. Mesmer és követôi, illetve a XX. században M. H. Erickson iskolája), vagy pedig csak a hipnotizált alany képességeire, hipnózis iránti fogékonyságára koncentrált (mint a hipnózis XIX. század végi elsố fénykorában J. M. Charcot, illetve a XX. században a hipnotikus fogékonyságot mérô standardizált skálák alkotói - részletesen 1. Bányai, 2000).

Ez a megosztottság előnyt jelentett ugyan a tudományos vizsgálódásnál elkerülhetetlen adatredukció szempontjából, azonban sajnálatos elméleti következményekkel is járt. A szerzók ugyanis aszerint, hogy a hipnotizôr vagy a hipnotizált szerepét hangsúlyozták és vizsgálták éppen, a hipnotikus jelenségek okait is hol csak egyikük hatásának, hol pedig másikuk fogékonyságának tulajdonították. Eközben mintha éppen a hipnózis lényege sikkadt volna el. Egyre inkább bizonyítottá vált ugyanis, hogy mind a hipnotizőrnek, mind a hipnotizáltnak meghatározó szerepe van a hipnózis létrejöttében és alakulásában.

Miután több mint tíz évig tanulmányoztam a hipnotizált alanyokban megjelenô pszichofiziológiai változásokat hagyományos relaxációs és az általam kidolgozott, aktivitásfokozó aktív-éber hipnózisban (Bányai, 2018a; Bányai és Hilgard, 1976), a 80-as évek elején arra a következtetésre jutottam, hogy a hipnózis jellegzetes kontextusban, két személy sajátos interakciója során, annak eredményeként alakul ki. Mechanizmusai feltárásához tehát a kontextust, valamint a résztvevô személyek - a hipnotizôr és alanya - kölcsönös egymásra hatását, azaz magát a hipnózis-interakciót kell vizsgálat tárgyává tennünk.

Ez a 80-as évek elején bekövetkezett szemléletváltás saját kutatási eredményeink és hipnoterápiás tapasztalataim mellett egyrészt a tudományos gondolkodás általános irányának megváltozásával - a rendszerszemlélet térhódításával (Von Bertalanffy, 1976) -, másrészt a pszichológiai elméletalkotás 80-as évekbeli változásával függött össze. Míg ugyanis azelôtt a pszichológia néhány, egymástól jól elkülöníthetố tényezô eredôjének fogta fel a viselkedést, a 70-es évek vége felé az elméletalkotók egyre inkább a rendszerszerú magyarázatok felé fordultak, a kölcsönös egymásra hatásokat 
kezdték hangsúlyozni (Bandura, 1978), és a viselkedést, a személyiségbeli és kognitív tényezôket, valamint a környezeti hatásokat mint egymást is kölcsönösen meghatározó, egymással elválaszthatatlan kapcsolatban lévô tényezóket kezdték vizsgálni.

A 80-as évek elején magában a hipnózisirodalomban is jelentkezett egy - a mi szemléletváltásunkkal lényegében rokon - tendencia. Megközelítôleg ugyanakkor, amikor elhatároztuk, hogy laboratóriumunkban tágabb interakciós szemléleti keretben folytatjuk a hipnózis tanulmányozását, tôlünk függetlenül mások figyelmét is felkeltette a hipnózis interaktív természete. Egyrészt - Freud, Ferenczi és más korai pszichoanalitikus szerzók újrafelfedezése nyomán - a klinikusok megújult érdeklődéssel fordultak a sajátos hipnoterápiás kapcsolat természete felé (összefoglalása: Diamond, 1984, 1987), másrészt a pszichoterápiás folyamat elemzése során az elméletalkotók éppen a hipnózis kiváltásának folyamatában ismerték fel a pszichoterápiás helyzet rendszerszerú modelljét (Haley, 1958; Fourie, 1983).

Az érzékelhetô szemléletváltás ellenére sajnálatosan kevés próbálkozás történt a hipnózis interakciós vonatkozásainak empirikus kutatására. Munkacsoportunk mellett, velünk szinte egy idôben mindössze három másik kutatócsoport kezdett interakciós szemléletû vizsgálatokat (Sheehan és McConkey, 1982; Lynn, Nash, Rhue, Carlson, Sweeney, Frauman és Givens, 1985; Nash és Spinler, 1989). E három munkacsoport azonban, bár az interakció fontos, eddig nem vizsgált aspektusait tette vizsgálat tárgyává (a személyközi klíma hatását, az önkéntelenség élményét, a kapcsolatot jellemzó archaikus bevonódást), a kutatás során csak az alany véleményére, érzéseire koncentrált, a hipnotizôrt jellemzó tényezôk hatását nem vizsgálta és nem elemezte.

Feltûnố az is, hogy még az interakciós szemléletû megközelítések is elhanyagolták a hipnotizôr és hipnotizált egymásra hatásának fiziológiai szintjét, holott, mint a hipnózis terápiás hatásai bizonyítják, a hipnózis során olyan élettani folyamatok (pl. immunválaszok) is szabályozhatókká válnak, amelyek a szokásos éber tudatállapotban nem befolyásolhatók.

Munkacsoportunk ezért olyan interakciós szemléletú megközelítés kialakítását tûzte ki célul, amelynek keretében a hipnotizôr és hipnotizált egymásra hatásának magatartási, élménybeli és kapcsolati dimenziója mellett az egymásra hatás élettani indikátorait is figyelembe vehetjük, illetve lehetôség szerint kísérleti körülmények között vizsgálhatjuk.

\section{TÖBBDIMENZIÓS INTERAKCIÓS SZEMLÉLETÚ KUTATÁSI PARADIGMA}

Kutatási paradigmánk két szempontból is interakciós szemléletú:

1. Ahelyett, hogy vagy csak a hipnotizáltra, vagy csak a hipnotizőrre koncentrálna, a hipnózis két résztvevôjének interakcióját vizsgálja és elemzi.

2. A hipnotizôr és a hipnotizált egymásra hatásának magatartási, élménybeli, kapcsolati és élettani dimenzióit egyaránt fontosnak tekinti, és hangsúlyozza e négy dimenzió interakcióját.

Az interakciós hangsúly mellett a megközelítés legfontosabb megkülönböztetố vonása szociál-pszichobiológiai nézőpontja. 
- Megközelítésünk a hipnózist úgy fogja fel, mint olyan módosult tudatállapotot, amely egy sajátos szociális kontextusban, egy hipnotizáltnak nevezett („címkézett”) személyben egy másik, hipnotizőrnek nevezett („címkézett”) személlyel való szociális, pszichológiai és élettani kölcsönhatás során alakul ki.

- A hipnózis kialakulását mind a hipnotizőr, mind a hipnotizált személyes tulajdonságai befolyásolják, hat rá kettejük kapcsolata, és hatnak rá a hipnózis létrehozását és tesztelését kísérô aktuális magatartási, szubjektív élménybeli és élettani változások.

- Szociál-pszichobiológiaijellegú megközelítésünk gyakorlati alkalmazásával nem feltétlenül ok-okozati összefüggéseket kerestünk a hipnózis résztvevooinek különbözó megnyilvánulásai között, hanem - a hipnózist folyamatosan változó rendszernek tekintve - e rendszer egyes elemei közötti kölcsönös összefüggések, kölcsönhatások feltárását túztük ki célul.

Munkacsoportunk 1982-tôl alkalmazza azt az interakciós szemléletú elemzést lehetôvé tevô kísérleti elrendezést, amelyben a hipnózis-interakciót komplex módon tanulmányozzuk.

Annak érdekében, hogy elkerüljük az előzmények esetleges torzító, befolyásoló hatását, és a hipnózis-interakciót teljes mértékben kontrollálni tudjuk, vizsgálatainkban általában olyan hipnózisokat figyelünk meg és regisztrálunk, amelyeknél a hipnotizôr és a hipnotizált nem ismeri egymást, életükben először a vizsgálat során találkoznak.

Több vizsgálatunkban elôször a hipnózis előtti attitûdöket, motívumokat és várakozásokat tártuk fel a hipnózis mindkét résztvevőjénél (Bányai, 2008). Az elôzetes elvárások feltárása után magát a hipnózis-interakciót regisztráltuk. A viselkedéses megnyilvánulásokat olyan videófelvételen rögzítettük, amely nemcsak a hipnotizált személyt, hanem a hipnotizôrt is mutatja, hogy mindkettôjük magatartását elemezni tudjuk. A hipnózisokról hangfelvételt is készítettünk, hogy az affektív prozódia változásait speciális hanganalízisnek vethessük alá. A magatartásváltozások elemzése nem korlátozódik pusztán a szuggesztiók végrehajtására; az interakció mindként résztvevôjének finom metakommunikatív jelzéseit - mosoly, egymásra tekintés, saját test érintés, testtartás, végtagmozgások stb. - szintén elemezzük.

A viselkedéses megnyilvánulások mellett több vizsgálatsorozatunkban elektrofiziológiai regisztrálást, illetve oxitocin- és kortizolszintmérést is végeztünk, hogy mind a hipnotizált, mind a hipnotizôr centrális és perifériális élettani változásait nyomon kövessük a hipnózis során (l. a jelen tematikus számban Kasos E. és mtsai tanulmányát, pp. 79-93.).

A hipnózis után - szintén az interakció mindkét résztvevôjénél - részletesen feltártuk a hipnózis-interakció során átélt élményeket, részben a munkacsoportunk által kialakított Párhuzamos Élményelemzô Technikával (PÉT, angol rövidítéssel PEAT), részben kérdôíves módszerekkel (1. Józsa, Költô, Bányai és Varga, pp. 27-43., illetve Varga tanulmányát a jelen tematikus számban, pp. 95-112.). A két résztvevô kapcsolatára, archaikus bevonódására vonatkozó jellegzetességeket is vizsgáltuk (l. Bányai, Józsa és Költố tanulmányát a jelen tematikus számban, pp. 45-61.).

A hipnózis magatartási, fiziológiai, élmény- és kapcsolati dimenziójára, valamint az alanyra és a hipnotizôrre vonatkozó adatokat elôször független elemzésnek vetettük alá, hogy az egyik dimenzióra, illetve az interakció egyik résztvevőjére vonatkozó ada- 
tok ne torzíthassák a másikat, majd a külön-külön kapott eredmények interkorrelációit is megvizsgáltuk. A szekvenciális analízis mellett azonban kifejezetten az interakció vizsgálatára alkalmas elemzéseket is végeztünk. Az interakciós szinkronitást - amelyrôl alább részletesen is írok majd - és a raportot mikroelemzéses módszerrel és holisztikusan egyaránt vizsgáltuk (Bányai, 2000, 2002; Biró és Bányai, 2007).

A nyers adatokat elôször a vizsgálatok célját illetôen naiv, független megítélốk elemezték, hogy az értékelést torzító elvárási hatásokat kiküszöböljük.

A jelen összefoglaló megírásáig összesen 61 hipnotizôr 932 hipnózis-interakcióját - 837 relaxációs és 95 aktív-éber hipnózisát - elemeztük a fenti komplex módon a szociál-pszichobiológiai szemléletû többdimenziós interakciós kísérleti paradigma keretében. Emellett adatokat gyújtöttünk 203 egészséges és 240 beteg személy hipnózissal kapcsolatos elképzeléseire, attitûdjeire, valamint 95 egészséges laikus és 46 hipnotizôr hipnózissal kapcsolatos mélyebb, rejtett motívumaira vonatkozóan is.

\section{AZ INTERAKCIÓS SZEMLÉLETÚ KUTATÁS FÔBB EREDMÉNYEI}

\section{A hipnózis résztvevőinek intraperszonális és interperszonális motivációja}

A hipnózis elôtti attitûdök, motívumok és várakozások felmérésének alapján az egészséges és beteg laikus személyeknél két közös elôzetes elvárás mutatkozott: valamenynyien tudati állapotmódosulást vártak - ezt többnyire alvásszerú állapotként írták le -, amelyben a hipnotizôr gondot visel rájuk és/vagy irányítja ôket. Intra- és interperszonális tényezôk tehát egyaránt motiválták óket a hipnózishelyzetre való jelentkezéskor (Bányai, 2008).

A hipnotizőrök és alanyaik félprojektív módszerrel végzett vizsgálatával kimutattuk, hogy mind a hipnotizőrök, mind a laikusok legtöbbször autoritáson, illetve intenzív pozitív érzelmi kapcsolaton alapuló szülő-gyerek viszony, orvos-beteg reláció, illetve szerelmi kapcsolat analógiájaként jelenítették meg a hipnózist. A történetek mintegy 10\%-ában jelent csak meg a személyes kapcsolat elhárítását jelzô önhipnózis (Bányai, 2000; Császár, 2001).

Vizsgálataink arra utalnak, hogy mind a hipnotizörök, mind alanyaik végsố soron a megszokott keretekbôl való kilépést keresik, ami lehetôvé teszi, hogy szokatlan élményeik legyenek, szokatlan módon viselkedjenek és szokatlanul intenzív kapcsolatba kerüljenek egymással.

\section{A „hipnóziskontextus” jelentôsége}

Mint már többen kimutatták, a hipnózisindukció alanyai akár a hipnotizốr személyes jelenléte nélkül, hangfelvételrôl kapott indukció hatására is végrehajtják a szuggesztiókat (Bányai, 2008). Ez igazolja a „hipnóziskontextus” fontosságát.

Amikor a hipnotizőr által személyesen kiváltott, illetve hangfelvétel alkalmazásával végzett hipnózis hatását összehasonlítottuk, azt találtuk, hogy a szuggesztiók végrehajtását tükrözố viselkedéses pontszám kis mértékben, de statisztikailag szignifikánsan 
magasabb volt a hipnotizőr által személyesen végrehajtott hipnózisokban. A szubjektív élményekben azonban a „magnós” feltétel esetén is megjelentek a tudati állapot hipnózisban bekövetkezô módosulásának szokásos jegyei, sốt archaikus bevonódás is kialakult a hangszórón keresztül megszólaló hipnotizôrre (Bányai, 2000).

Az élménybeszámolók arra utaltak, hogy a „gépi” indukció esetén a hipnotizốr személyes jelenlétét a kutatólaboratórium tágabb szociális környezete pótolta. Eredményeink szerint a laboratórium ismertsége, presztízse, atmoszférája jelentôsen befolyásolta az élményeket. Annak ellenére, hogy a magnetofonról hallott hang számukra ismeretlen személyé volt, az alanyok hipnózis utáni élménybeszámolói hangsúlyozták a bizalom fontosságát, amit itt a kontextus biztosított.

\section{A hipnózis iránti fogékonyság (hipnábilitás) szerepe}

A hipnózis iránti fogékonyság - azaz a standard körülmények között elért szuggesztió-végrehajtás és hipnózismélység - igen stabil személyiségvonás. Hátterében örökletes tényezók (Szekely, Kovacs-Nagy, Bányai, Gôsi-Greguss, Varga, Halmai, Ronai, Sasvari-Szekely, 2010) és a korai szocializáció hatásai (l. Költő, Józsa és Bányai tanulmányát a jelen tematikus számban, pp. 63-78) egyaránt kimutathatók.

Az alanyok hipnábilitása jelentôsen befolyásolta a hipnózis-interakció többi tényezôjének alakulását. Az erôsen fogékonyak (továbbiakban: erôsek), akik viselkedéses szinten rugalmasan követték és végrehajtották a hipnotizőr verbális szuggesztióit, hipnózisuk mélységét szubjektíve is az éber állapottól eltérôbbnek ítélték, mint a gyengén hipnábilis alanyok (továbbiakban: gyengék) (Bányai, 2000). A Tudat Fenomenológiája Kérdôív (PCI) alkalmazásával is erôsebb tudati változásokról adtak számot, mint a gyengék, mind hagyományos relaxációs hipnózisban (l. Józsa, Költő, Bányai, Varga tanulmányát a jelen tematikus számban, pp. 27-43.), mind aktív-éber hipnózisban (Kasos E., Kasos K., Józsa, Költő, Bányai és Varga tanulmánya a jelen tematikus számban, pp. 79-93.).

Az alanyok hipnábilitása agyi elektromos aktivitásuk alakulásával is jellegzetes öszszefüggést mutatott. A háttér EEG változásainak nyomon követésével több kísérletben igazoltuk, hogy erôseknél az indukció hatására a globális féltekei aktivitásban jobb oldali múködési túlsúly alakul ki (Bányai, 1985, 2000). A gyengék ezzel szemben a háttér EEG-ben az indukció elôrehaladtával egyre erôsebb bal agyféltekei múködési túlsúlyt mutatnak (Bányai, 1985, 2000). Náluk a hipnózisindukció - úgy túnik - még tovább növeli a „bal féltekés” verbális, elemzó múködésmódot. Erre utal az is, hogy a hipnotizốr figyelemelterelố múveleteire úgy reagáltak, mintha még inkább „résen lennének”. Gyakran fordult elô, hogy náluk a deindukció (régebbi terminológiával: dehipnózis) során jelent meg jobb agyféltekei múködési túlsúly. Ilyenkor arról számoltak be, hogy úgy érezték, ekkor tudtak volna igazán mély hipnózisba kerülni (azaz akkor, amikor már nem állt fenn a „veszélye” annak, hogy a hipnotizőr szuggesztiói irányítsák viselkedésüket, tehát hogy átadják a kontrollt a hipnotizőrnek).

Aktív-éber hipnózisban egy perifériális mutató, az elektrodermális aktivitás vizsgálatával ugyancsak kimutattuk, hogy míg alacsony hipnábilitású alanyoknál az indukció végén is megmarad a mindennapi éber tudatállapotra jellemzô bal féltekei dominan- 
cia, addig az erôseknél jobb féltekei túlsúly alakul ki (Kasos E., Kasos K., Józsa, Költô, Bányai és Varga tanulmánya a jelen tematikus számban, pp. 79-93.).

A háttér EEG vizsgálata demonstrálta, hogy a szuggesztiók végrehajtásakor a hipnábilis személyek igen gyors és rugalmas változásokat mutatnak az agyféltekék múködési túlsúlyában (Bányai, 2015). Például képzeleti feladatoknál hipnózisban markáns jobb féltekei, analitikus feladatoknál bal féltekei múködési túlsúlyt regisztráltunk náluk. Az eseményhez kötött potenciál (EKP) vizsgálatok is az erôsek figyelmének rugalmasságát mutatják (Bányai, 2015).

A populáció zömét kitevô közepesen hipnábilis személyek hipnózisaiban akkor jelent meg viszonylagos jobb agyféltekei múködési túlsúly, ha az adott alkalommal szubjektíve mély hipnózist éltek át, és a szuggesztiók közül sokat végrehajtottak (Bányai, Mészáros, Csókay, 1985). Ilyenkor arról számoltak be, hogy sikerült „jól összehangolódniuk" a hipnotizôrrel (ennek jeleit késôbb részletezem).

A hipnotizôrök hipnábilitása nem mutatott összefüggést sem az alanyok szuggesztió-végrehajtásával, sem szubjektív élményeik alakulásával, sem háttér EEG-jük múködési túlsúlyával (Bányai, 2000, 2008). Pozitív összefüggés mutatkozott azonban a hipnotizőrök hipnotizálás alatti tudati állapotmódosulása és hipnábilitása között (Varga, Józsa és Kekecs, 2014). A hipnotizőrök háttér EEG-je nemcsak az alanyok, hanem saját hipnábilitásuk mértékével sem mutatott összefüggést. A standard indukció felolvasása alatt a hipnotizôrök EEG-jének bétatartományában a teljesítmény - a verbális „feladatnak” megfelelően - az erôsen és gyengén hipnábilis hipnotizőrök hipnózisai során egyaránt erôs bal féltekei túlsúlyt mutatott, a szabadon megfogalmazott mélyítô szuggesztiók alatt viszont - amikor viselkedésükben sok interakciós szinkronjelenség jelent meg (l. késôbb) - a hipnotizôrök két féltekéjének aktivitása kiegyenlítetté vált (Bányai, 1985, 2000). Ez a kiegyenlített agyféltekei múködésmód nagy gyakorlattal rendelkezô jógamesterek EEG-jében is megjelenik (Vaitl és mtsai, 2005) és valószínúleg az elemzó és egészleges múködésmód integrálódásával, a másikhoz való intenzív odafordulás közben megtartott kontrollal függ össze.

\section{Interakciós szinkronitás (ISZ)}

Már interakciós vizsgálataink korai szakaszában, 1984-ben felfigyeltünk egy különös jelenségre: az alanyok hipnózisa szubjektíve hirtelen mélyebb lett, ha interakciós szinkronitás - továbbiakban: ISZ - lépett fel (Bányai, Mészáros és Csókay, 1984).

Az ISZ fogalmát Condon (1982) az 1960-as években vezette be az interakció szakirodalmába. Eredetileg azt a folyamatot jelentette, melynek során a hallgató testmozgásainak és a beszélố szóbeli megnyilvánulásainak változásai között megfelelés, összehangolódás alakul ki. A személyek viselkedése között illeszkedés, ritmikus szervezettség jön létre (Chapple, 1982) az egyéni viselkedés koordinációja, egymás kölcsönös befolyásolása (Cappella, 1981) révén. Az ISZ jelenségeinek leírására, evolúciós gyökereinek, funkcionális jelentôségének feltárására irányuló igen gazdag szakirodalom szerint (áttekintése: Biró, 2003) az ISZ fogalma késóbb átalakult. Ma a legkülönbözóbb egyéni ritmusok interperszonális kontextusban történó összehangolódását, idôi koordinációját foglalja magában (Biró és Bányai, 2007). 
A kutatási eredmények azt mutatják, hogy az ISZ-nak fontos szerepe van az interakciók szabályozásában: megfelelő összehangolódás esetén az interakciót gördülékenynek és harmonikusnak érezzük, szimpátiát érzünk a másik személy iránt (Chatrand és Bargh, 1999), raport alakul ki (Tickle-Degnen és Rosenthal, 1990, 1992). Az ISZ a szoros emberi kapcsolatok alakulásában is központi jelentôségú: szerepe van a gyermek- és felnôttkori kötôdés kialakulásában és minôségének meghatározásában (összefoglalása: Bányai, 2008; Biró, 2003). Mivel a szoros kapcsolatok hiánya nehezíti a stresszel való megküzdést, az ISZ a testi és lelki egészség fenntartásában is szerepet játszik (Burleson, Albrecht és Sarason, 1994; Heller és Rock, 1997; House, Landis és Umberson, 1988; Sarason, Sarason és Gurong, 1997).

A korai kapcsolatok interakciós mintázatai a csecsemó szelffejlódésében is kitüntetett szerepet játszanak: megalapozzák az interszubjektivitás (Baker, 2000) és a késóbbi önszabályozás folyamatait is (Gergely, 2003; Gergely és Watson, 1996/1998; Kraemer, 1992; Stern, 1985, 1999; összefoglalását l. Biró, 2003). Csányi (1999) szerint az együttmúködésben rejló túlélési eloonyök evolúciós nyomására alakultak ki az interakciós szinkronitás alapjául szolgáló élettani és viselkedéses mechanizmusok (Chatrand és Bargh, 1999; Hatfield, Cacioppo és Rapson, 1994), amelyek funkciója a csoporttagok érzelmi állapotainak, viselkedésének összehangolása.

A szakirodalomban ellenôrzött vizsgálatok alapján elôször munkacsoportunk írta le, hogy a hipnózis-interakció során ISZ jelenik meg. Kezdetben mikroelemzéses módszerekkel, késôbb egészleges megítéléssel (módszertani összefoglalása: Biró, 2003) kimutattuk, hogy viselkedéses szinten gyakran figyelhetó meg tükörtartás, együttmozgás - amikor például a hipnotizốr saját kezének mozgásával kíséri a motoros szuggesztiók végrehajtását - és mikroszinkronitás - amikor a hipnotizált valamely testrészének, például kezének rövid idôtartamú mozgását a hipnotizôr más testrészeinek, például lábfejének hasonló idôtartamú mozgása kíséri. A hipnózisindukciók előrehaladtával, a hipnózis mélyülésekor figyelhetô meg az a gyakori szinkronjelenség, amelynél a hipnotizốr - többnyire felsôtestének ritmikus („kántáló”) mozgásával - követi a hipnotizált légzésének ritmusát (Bányai, 1985, 1991, 1998, 2000, 2002; Bányai és mtsai, 1990; Biró és Bányai, 2007).

Élettani szinten is kimutattunk ISZ-t: leírtuk, hogy egyes hipnózisokban a hipnotizôr és hipnotizált légzésritmusának összehangolódása szoros összefüggést mutat a hipnózis mélyülésével (Bányai, 1991, 1998, 2000, 2002; Bányai és mtsai, 1990; Biró és Bányai, 2007); az izmokról elvezetett elektromos aktivitás szerint gyakori az együttes ellazulás, illetve bizonyos szuggesztiók - például karkatalepszia - végrehajtásakor az együttes izomfeszülés, s gyakran a szívritmus gyorsulása és lassulása is párhuzamosan következik be (Bányai, 1985; Bányai, Mészáros és Csókay, 1985). Az ISZ megjelenésének gyakorisága és idôtartama nem annyira a hipnotizált személyiségtényezôivel, mint inkább a hipnózis stílusával függ össze. (Errôl az összefüggésrôl részletesen 1. késóbb.)

A vizsgálatainkban szigorúan ellenôrzött körülmények között, több mutatóban regisztrált ISZ empirikus bizonyítékokkal támasztja alá azokat a terápiás megfigyeléseken alapuló állításokat (pl. Erickson, Rossi és Rossi, 1976), amelyek szerint a hipnózis kialakulásában és eredményességében fontos, hogy a hipnotizőr „ugyanazon a hullámhosszon legyen”, mint alanya. 


\section{Kölcsönös archaikus bevonódás}

A speciális hipnotikus kapcsolat, a raport Mesmer óta központi fogalom a hipnózissal foglalkozó irodalomban (Bányai, 2008; Bányai, Varga és Gôsiné Greguss, 2001; 1. Bányai, Józsa és Költô a jelen tematikus számban, pp. 45-61.).

A hipnózis kapcsolati dimenziója a klinikumban mindig is fontos tényezônek számított, és az 1980-as években ismét az érdeklődés homlokterébe került (Chertok, 1981; Copeland, 1982; Diamond, 1984, 1987). A hipnózis reneszánszát kiváltó kísérleti hipnóziskutatás kezdetben sajnálatosan figyelmen kívül hagyta a kapcsolati tényezók jelentôségét. Shor $(1962 / 2008,1979)$ volt az elsô, aki empirikus munkái alapján a pszichoanalitikus szerzókkel egyetértésben a hipnózis egyik alapvetô dimenziójának tekintette a hipnotizôr és hipnotizált speciális kapcsolatát, melynek az archaikus bevonódás nevet adta. Bár Shor (1962/2008) szerint az archaikus bevonódás kísérleti körülmények között nem alakul ki, az 1970-es évektôl több kutatócsoport is megkezdte a jelenség empirikus vizsgálatát (l. Bányai, Józsa és Költố tanulmányát a jelen tematikus számban, pp. 45-61.).

Nash és Spinler (1989) a jelenség mérésére kidolgozta az Archaikus Bevonódási Skálát (ABS). Munkacsoportunk interakciós vizsgálataiban a PÉT-tel végzett élményfeltárás során rendszeresen jelentek meg áttételi jellegú tartalmak, nemcsak az alanyoknál, hanem a hipnotizôröknél is, és az áttételi kapcsolat többször negatív érzelmi színezetû volt (Bányai és mtsai, 1990; Varga, 2017; Varga, Bányai és Gôsi-Greguss, 1994). Ezért az eredetileg csak a hipnotizált archaikus bevonódását mérô ABS-t a hipnotizôrre is kiterjesztettük, és emellett a negatív affektív színezetû áttételi reakciók mérésére alkalmas skálarésszel is kiegészítettük. Az alany és hipnotizôr ABS-kérdőívek bemutatását és a velük végzett vizsgálatok eredményét Bányai, Józsa és Költô tanulmánya (a jelen tematikus számban, pp. 45-61.) részletesen tárgyalja.

Az ABS alkalmazásával végzett vizsgálataink egyik legfontosabb eredménye az, hogy a hipnotizôrök hasonló mértékú archaikus bevonódást mutatnak az alanyok iránt, mint fordítva: az archaikus bevonódás tehát nem egyoldalú, hanem kölcsönös jelenség. Az archaikus bevonódás mértéke és a szimpátia között sem a hipnotizáltaknál, sem a hipnotizôröknél nincs korreláció (Bányai, 2000, 2008). Ez úgy értelmezhetô, hogy az archaikus bevonódás a kapcsolat független dimenziója: azt tükrözi, hogy a hipnózis-interakció résztvevôi milyen áttételi készséggel lépnek be a hipnózishelyzetbe. Mivel a két fél archaikus bevonódása hasonló mértékú, úgy tûnik, az alany és a hipnotizôr egyaránt kész korábbi érzelmi viszonyulási mintái átélésére, azaz arra, hogy hipnózis során a szokásosnál intenzívebb érzelmi kapcsolatba kerüljön egy számára addig idegen emberrel.

\section{Hipnózisstílusok}

Kutatásaink elméleti szempontból legfontosabb eredményének talán a hipnózisstílusok leírása tekinthetô. Felfigyeltünk rá, hogy a hipnózis-interakciók során megjelenô ISZ mennyiségében nagy eltérések mutatkoznak, ezért szisztematikus összehasonlító vizsgálat tárgyává tettük az ISZ megjelenési gyakoriságát és időtartamát az egyes hipnózisokban. Ezután megvizsgáltuk, van-e összefüggés az ISZ mennyisége és az interakció 
egyéb jellemzôi között. Feltártuk, hogy a különbözô mennyiségú ISZ-sal jellemezhetô hipnózisok jellegzetes magatartási, élmény- és archaikus bevonódási különbségekkel járnak együtt. Míg a több ISZ-t mutató hipnózisok után a hipnotizőrök gyakran saját testi-fizikai bevonódásával jellemezték az eseményeket, valamint számos énközeli élményrôl, emlékrôl számoltak be, a kevesebb ISZ-sal járó hipnózisok után a hipnotizôrök élményei inkább kognitív-racionális bevonódásra utaltak. Az ISZ-mutatók és a magatartási, élménybeli és kapcsolati sajátosságok mintázatai alapján elôször két jellegzetes hipnózisstílust különítettünk el: az egyikre inkább a testi-fizikai munkamód, a másikra a kognitív-racionális munkamód volt jellemzó (Bányai és mtsai, 1990).

E két stílus már az interakció kezdetén is elkülönül egymástól. A testi-fizikai bevonódású hipnózisokban a hipnotizôr barátságosabb, családiasabb hangulatban kezdi a kapcsolat kialakítását (pl. többször szólítja keresztnevén az alanyt, bíztatja, hogy kérdezzen, engedi hosszabban beszélni), a kognitív-racionális munkamódú interakciókban a hipnotizôr a raportalakításkor inkább gátolja a hipnotizálandó személyek spontán megnyilvánulásait, ó maga beszél többet. A szuggesztiók viselkedéses végrehajtása, illetve az alanyok szubjektív hipnózismélysége nem tükrözi a hipnózis stílusának különbségeit, a szubjektív élményekben és archaikus bevonódásban viszont finom eltérések mutatkoznak. A fizikai-testi munkamódú hipnózisoknál gyakran figyelhetô meg párhuzamosság, együttesség az alany és a hipnotizôr élménybeszámolója között, míg a másik stílusnál inkább komplementer jellegú, mintegy „kiegyenlítő” élmény, illetve archaikus bevonódás jelenik meg az interakció résztvevooinél (Bányai és mtsai, 1990).

Az általunk empirikusan körvonalazott hipnózisstílusbeli különbségek erôsen emlékeztetnek a Ferenczi Sándor (1909/2000) által feltételezett különbségre az inkább szeretetre épülô „anyai” és az inkább félelemre alapozó „apai” hipnózis között. A testi-fizikai bevonódást mutató hipnózisok a korai anya-gyerek interakciók szinte szimbiotikus testi együttességére emlékeztetnek, s így az „anyai” hipnózisra hasonlítanak, a kognitív-racionális hipnózisokra viszont az „apai” hipnózis metaforája alkalmazható (Bányai, 1991). Az „anyai” és „apai” hipnózisstílus mint metafora jól értelmezhetônek bizonyult még a laikusok számára is, ezért 1991 óta munkacsoportunk ezt az elnevezést használja, és így utal rá a szakirodalom is (pl. Whitehead, Noller és Sheehan, 2008).

Az anyai és apai hipnózisstílust kezdetben a hipnotizór személyes stílusaként azonosítottuk (Bányai, 1991; Bányai és mtsai, 1990). A testi-fizikai munkamódú „anyai” hipnotizôr ugyanis általában fóként a hipnotizált testi változásaira (testtartás, izomtónus, gyomorkorgás stb.) figyelt, ezek alapján módosította metakommunikációját a hipnózisindukció során. A kognitív-racionális „apai” hipnotizôrre inkább az volt általában jellemzô, hogy szakmai, racionális elemzés alapján módosította kommunikációját. Mivel a hipnotizáltak élményeiben akkor jelentek meg pozitív tartalmak, amikor a hipnotizőrök „kedvenc” munkamódjukat alkalmazták (Bányai és mtsai, 1990), a jellegzetes eltéréseket a hipnotizôr stílusának tulajdonítottuk.

A késôbbiekben azonban a hipnózis-interakció komplex vizsgálatát kiterjesztettük a hipnotizôrök és alanyaik rejtett kapcsolati elvárásaira is. A kapcsolati motivációra is kiterjedô, több hipnotizôrt és többféle - relaxációs és aktív-éber - hipnózistechnikát felölelô vizsgálataink feltárták, hogy a hipnózisstílusok árnyaltabb értelmezésére van szükség. 
Kimutattuk, hogy a különbözó motívumokkal érkezô hipnotizóröknél és hipnotizáltaknál különbözô utak vezethetnek a viselkedéses szinten azonos „teljesítmény”, (szuggesztió-végrehajtás) eléréséhez. Az intenzív érzelmi kapcsolati igényú hipnotizőröknél inkább „anyai” stílusú - nagyobb testi-fizikai, illetve élménybevonódással jellemezhetô - hipnózisokat regisztráltunk. A hipnózisban a távolságtartás eszközét keresố hipnotizôrök hipnózisai inkább a kognitív-racionális stílusú hipnózis jegyeit mutatták. A hipnotizőrök motivációja tehát fontos meghatározója volt a hipnózis stílusának. Az alanyok elvárásai - amelyekre többnyire már az interakció kezdeti fázisában, a raportalakításkor utaltak - esetenként szintén erôsen módosították az aktuális interakció kimenetelét. A hipnózis-interakció stílusa tehát végeredményben a két személy igényeinek tudattalan egyeztetési folyamatában alakul ki, s így ugyanaz a hipnotizôr különböző alanyokkal eltérô mértékben lesz „anyai”, illetve „apai”.

Szisztematikus vizsgálataink azt is feltárták, hogy nem minden hipnózis sorolható be az „anyai” vagy „apai” stílusú hipnózisok közé. Egyrészt néhány hipnózis után az élmények erôs erotikus színezetre vagy testvéri érzésekre utaltak (Varga, Bányai és Gôsi-Greguss, 2004), másrészt az aktív-éber hipnózisok után az alanyok legtöbbször „barátinak” minôsítették a hipnózis stílusát (Bányai, 1998, 2000, 2002). Az aktív-éber hipnózisok a külsố megfigyelôk számára is szimmetrikusabb kapcsolati mintázatot mutattak (Bányai, 2002; Pusztai, 2017).

A hipnózisstílusokra jellemzô magatartási, élettani és élményadatok elemzése alapján azt a következtetést vontuk le, hogy a hipnózisstílusok az élet legfontosabb intim személyközi kapcsolatainak stílusára emlékeztetnek (Bányai, 1998, 2000, 2002), amelyek a magatartás, a testi funkciók és az élmények szempontjából szabályozó szerepet töltenek be.

A „hipnózisstílus” konstruktum érvényességét és megbízhatóságát elsô leírása óta több vizsgálatsorozattal és többféle - egészleges, illetve jellegzetes vonásokon alapuló - megítélési módszerrel igazoltuk, standard hipnózisok (összefoglalásuk: Bányai, 2000, 2002, 2008; Varga és Kekecs, 2015) és a terápiás hipnózisokhoz közelebb álló, szabad indukciót és standard szuggesztiókat alkalmazó „félig kötött” hipnózisok esetén egyaránt (Bányai, 2000, 2002).

A konstruktum érvényességét az is bizonyítja, hogy a külsô szemlélôk által megítélt „anyaiság” és „apaiság” mértéke jól értelmezhetô összefüggéseket mutat a hipnózis-interakció résztvevôinek élményeivel. Az interakció minôségének jellemzésére laboratóriumunkban kifejlesztett Diádikus Interakciós Harmónia kérdôív (DIH) (Varga, Józsa, Bányai és Gôsi-Greguss, 2006) alkalmazásával kimutattuk, hogy minél anyaibbnak értékelik a stílust a külsô megítélôk, az interakció mindkét résztvevôje annál több játékosságot, összhangot és feszültséget él meg a hipnózis-interakció során (Varga, Bányai, Józsa, Gôsi-Greguss, 2008). A PCI-vel mért tudatmódosulás mértéke nem mutat öszszefüggést a hipnózisstílussal, a különbözô stílusú hipnózisok tehát egyaránt eredményezhetnek módosult tudatállapotra jellemzó élményeket (Varga és mtsai, 2008).

Az anyaibbnak ítélt hipnózisok az érzelmek erôsebb kifejezésével járnak együtt. Mind a hipnotizőrök, mind alanyaik gyakrabban és hosszabban mosolyognak, fơként az interakció kezdeti és befejezó szakaszában, és élményeikben mind a pozitív, mind a negatív érzelmek intenzívebben jelennek meg. Az anyaibb hipnózisokban a hipnotizőröket független megítélôk szignifikánsan kifejezóbbnek ítélték, mint az apaibb 
hipnózisok hipnotizőreit. Az anyaibb hipnotizôrök intenzívebb testi bevonódását jelezte, hogy gyakrabban érintették meg alanyaikat, és gyakrabban törekedtek testkontaktusra - fơként a fájdalmas jegesvíz teszt alatt -, mint az apai hipnotizôrök (Bányai, 2000, 2008).

Az élmények is jellegzetes kapcsolati mintázatot mutatnak. Egyfelól az anyaibb hipnózisok hipnotizốrélményeiben több jegy a tudati állapot módosulására utal - metaforikusan a hipnotizôr ilyenkor az élményben is a „hipnotizálttal tart”. Másfelól az apaibb hipnózisok hipnotizórélményei gyakran negatív korrelációt mutatnak az alanyok élményeivel - mintha a hipnotizôr az élményben komplementer módon „ellentartana (Bányai, 2000, 2002, 2008; Varga és mtsai, 2008).

Az aktív-éber hipnózisoknál a stílusok egészleges megítélése az anyai és baráti stílusok esetében, a vonásokon alapuló megítélés az anyai, baráti és testvéri stílusok esetében bizonyult megbízhatónak (Bányai, 2000, 2002, 2008; Pusztai, 2017). Úgy túnik tehát, hogy nem csupán a hipnotizáltak maguk, hanem külsô megítélők is egyenrangúbb, szimmetrikusabb kapcsolódási mintát fedeznek fel az aktív-éber eljárás interakciójában, ami a hipnózis teljes idôtartama alatt megkívánja a hipnotizált aktivitását.

A hipnózisstílus megítélésének megbízhatósága az anyai stílus esetében a legnagyobb: ennek mértékét mind egészleges, mind vonásokon alapuló megítélés alapján még hipnózisban és pszichoterápiában képzetlen laikusok is megbízhatóan ítélik meg relaxációs és aktív-éber hipnózisok esetén egyaránt (Bányai, 2002, 2008; Pusztai, 2017; Varga és Kekecs, 2015). Ez arra utal, hogy az anyai hipnózis-interakciók jellege valóban feltûnôen hasonlít az anya-gyerek interakciókra.

\section{Kölcsönhatások a hipnózis-interakció különbözó tényezói között}

Az élettani, viselkedéses, élmény- és kapcsolati dimenzióra vonatkozó adatok interkorrelációinak elemzése lehetôvé teszi, hogy következtessünk a hipnózis kialakulását elôsegítô közvetítô mechanizmusok természetére. Úgy tûnik, hogy a hipnózis alanyának hipnábilitása, valamint a hipnotizôr hipnábilitása és kedvenc munkamódja egymással kölcsönhatásban határozza meg az alanyok hipnotikusan módosult tudatállapotának kialakulását. Ezt a szuggesztiók végrehajtása mellett az agyféltekék múködési túlsúlya és az élménymutatók alakulása is tükrözi. Az eltérô stílusú és hipnábilitású hipnotizôrök különbözôképpen reagálnak a hipnotizáltak által nyújtott finom jelzésekre, és más eszközöket használnak a hipnózis elmélyítésére.

A döntően testi-fizikai munkamódú „anyai” hipnotizőr az interakciós szinkronitást „eszközként” használhatja, hogy alanyával ,azonos hullámhosszra kerüljön”. Azonos testtartást vesz fel, együtt mozog, lélegzik a hipnotizálttal, s így érzéseihez is közelebb kerülhet. Egyik kísérletünk döntôen anyai stílusú (gyengén hipnábilis) hipnotizôrje például az ellentétes nemú és erôsen hipnábilis személyekkel mutatta a legtöbb ISZ-t (Bányai, 1991, 2000; Bányai és mtsai, 1990). PÉT-tel feltárt élményeiból kiderült, hogy - bár hipnotizálás közben nem volt tudatában annak, hogy együtt mozog vagy lélegzik a hipnotizálttal - mindvégig saját testérzéseiból következtetett az alanyban végbemenó változásokra, tehát az ISZ valóban közvetítôként szolgált számára. 
A döntốen kognitív-racionális stílusú hipnotizôrök inkább saját szempontjuk erôteljesebb hangsúlyozását használják eszközként a hipnózis mélyítésére. Minél apaibb stílusú a hipnózis, annál többször utalnak például önmagukra a raport kialakulását célzó beszélgetés során (Bányai, 2002), és hajlamosak arra, hogy - önkéntelenül - eltérjenek a standard szövegtốl (Gôsiné Greguss, 1996). Amikor egy erôsen vagy közepesen hipnábilis, döntôen apai stílusú hipnotizôr az erôs hipnábilitás jeleivel találkozik, inkább növelni igyekszik a távolságot maga és alanya között, így érthetố, hogy élményeiben nem tart vele, hanem inkább komplementer módon „ellentart” (Varga és mtsai, 2008).

A standard szövegú hipnózisindukcióknál a standardtól való eltérés mellett a hipnotizőrök affektív prozódiájának változásai is közvetítô szerepet játszanak. A hanglejtés és hangszín változása olyan erôs hatást gyakorolhat a hipnotizáltakra, hogy még a verbális „üzenet” tartalmát is felülírhatja (Bányai, 2008). A prozódia hipnózis-interakcióban játszott szerepét célzott, a hangelemzés modern számítógépes módszereit és a hangváltozások szubjektív skála alapján történô megítélését egyaránt felhasználó - a szakirodalomban egyedülálló - kutatásokkal vizsgáltuk. Kimutattuk, hogy a hipnotizőrök hangjának mélyülése, beszédsebességük lassulása, hangmagasságuk variabilitása, intenzitása és a hangszínváltozást jellemzố hosszú idejú átlagos spektruma (HIÁS) az egyénre jellemzô bonyolult összefüggéseket mutat az alany állandóan változó állapotával (Gôsiné Greguss, 2002, 2003; Gốsi-Greguss, Bányai, Józsa, Suhai-Hodász és Varga, 2004). A szubjektív megítélések eredményei jól korreláltak az objektív paraméterekben mért változásokkal. Relaxációs hipnózis során a hipnotizôrök beszéde „álmosabb", lassabb, nyugodtabb, halkabb és dallamosabb, éneklôbb lett az indukció elejéhez képest az indukció végén. Az, hogy a számítógépes hangelemzó módszerrel nyert eredmények és a hangváltozások szubjektív skálázásos megítélése jól korrelál egymással, arra utal, hogy a prozódia változásait - ha nem is tudatosan - minden bizonnyal a hipnotizáltak is érzékelik, és ez szerepet játszhat tudati állapotuk és élményeik alakulásában.

A hipnotizôrök beszédsebessége a hipnotizált életkorával és nemével sem mutatott összefüggést. Jellegzetes összefüggések voltak azonban kimutathatók relaxációs hipnózisban a beszédsebesség és a hipnózis átélését jellemzô élménymutatók között (részletesen 1. Bányai, 2008). Az eredmények összességükben arra utalnak, hogy relaxációs hipnózisban - az ellazult állapot miatt - a hipnotizáltak lassú beszédet várnak el a hipnotizôrtổl. Ha ez nem kellốen lassú, azaz szerintük nem felel meg a helyzetnek, kialakul ugyan a hipnotikus állapot, de az élmény-, kapcsolati és interakciós mutatók (PCI, ABS, DIH) jelzik, hogy feszültség zavarta meg az egymásra hangolódást.

Az interakció résztvevőinek neme moderálta az összefüggéseket. Az ellentétes nemúek hipnózis-interakciói során gyakrabban jelent meg a résztvevốk feszültségét jelzố zavarjel (pl. sajáttest-érintés), mint az azonos nemúek interakciói során (Bányai, 2000).

Azoknál a hipnózis-interakcióknál, amelyekre az ISZ viselkedéses és élettani szintjének gyakori megjelenése jellemzô, a PÉT-tel feltárt élmények szintjén is feltûnô az alany és hipnotizốrje közötti egybecsengés, a fenomenológiai szintủ ISZ (Bányai, 2008; Varga tanulmánya a jelen tematikus számban, pp. 95-112.). 


\section{A HIPNÓZIS SZOCIÁL-PSZICHOBIOLÓGIAI MODELLJE}

Interakciós vizsgálataink eredményei támogatják azt az elképzelést, hogy a hipnózis felfogható több tényezô dinamikus egymásra hatása során kialakuló adaptív rendszernek, amelyben bármely tényezó változ(tat)ása a rendszer többi elemének megváltozását eredményezi.

Eredményeink szerint azzal, hogy egy sajátos szociális kontextusban „hipnózisnak” címkézünk egy helyzetet, lehetôvé tesszük, hogy két felnőtt személy - kontrollált körülmények között - védett helyzetben, rövid ideig, különösebb kockázat nélkül olyan intenzív kapcsolatba kerüljön egymással, amely egyébként csak a szoros, intim személyközi kapcsolatokra (pl. szülő-gyerek viszonyra) jellemzô. Ebben a helyzetben a hipnózis a folyamat mindkét résztvevôje számára olyan feszültség- és ingerbemenet-szabályozó funkciót tölthet be, amely általában ugyancsak a szoros, intim személyközi kapcsolatok sajátja, s amelynek központi szerepe van a szervezet jó közérzetének és optimális arousalszintjének fenntartásában.

A kognitív és személyközi összehangolódást biztosító hipnózisindukció hatására a hipnózis alanyában markáns pszichofiziológiai változások következnek be. Ha az alany közepesen vagy erôsen hipnábilis, és összehangolódik a hipnotizőrrel, a „bal féltekés”, elemzô múködésmódról egészlegesebb, érzelmi hatásokra és szuggesztiókra nyitottabb múködésmódra vált át. Még a gyengén fogékony személyek is mutatnak ellazulást, a háttér-EEG-ben az éber állapothoz képest több theta aktivitást (Bányai, 2015), valamint endokrinológiai változásokat (1. Kasos és mtsai tanulmánya a jelen tematikus számban, pp. 79-93.). Ez lehetôvé teszi, hogy túltanult, esetleg maladaptív kognitív és magatartási sémáik a hipnotizôr szuggesztiói hatására pozitív irányban változzanak.

Hipnózis során új élmény- és magatartásmódok jelenhetnek meg, mintegy új horizontok tárulhatnak fel a folyamat mindkét résztvevôjénél. Ennek következtében mindkettôjük társas és biológiai adaptációja hatékonyabbá válhat. Ez lehetôvé teszi, hogy a folyamatot kontrolláló, egészséges, jól adaptált szakember - a hipnotizôr, terápia esetén a hipnoterapeuta - segítsen abban, hogy a hipnotizált (terápia esetén a páciens) társas kapcsolatai, magatartása és élettani folyamatai egészségesebbé váljanak.

A szociál-pszichobiológiai modell nézôpontjából a hipnózis olyan helyzetekkel és viselkedésekkel rokon, amelyek lehetôvé teszik az új lehetôségeket felfedezô és kipróbáló, adaptív „hipotézis-magatartást” (Grastyán, 1985). Ilyen helyzetek például a jól múködô szoros intim kapcsolatok, a játék, a kreatív alkotási folyamat, a csúcsélmények, a vallásos megvilágosodás pillanatai - az emberiség ôsi közös élményei. Mivel a hipnózis szigorúan ellenőrzött laboratóriumi körülmények között vizsgálható, alkalmas lehet arra, hogy ezeket az evolúciósan ôsi, ám talán mégis a fejlôdés motorját jelentô funkciókat tudományosan tanulmányozzuk a segítségével.

\section{A SZOCIÁL-PSZICHOBIOLÓGIAI MODELL GYAKORLATI, TERÁPIÁS JELENTÓSÉGE}

A hipnózis szociál-pszichobiológiai modellje szerint a hipnotikus kapcsolat alkalmas lehet arra, hogy segítsen a hipnózisban lévô személynek korrektív érzelmi és kognitív élmé- 
nyekhez jutni, hiszen a hipnózis-interakcióban a korai érzelmi kapcsolati minták élednek fel. Kognitív szemléletû fejlôdés-lélektani vizsgálatok megerôsítik ezt a lehetôséget (Posner, Rothbart, 2011). Ezek arra utalnak, hogy a hipnózisbeli kognitív kontroll a korai életkorra jellemzô, külsố ingerekre épülô „orientációs” hálózatra való erôsebb támaszkodással analóg, szemben a késôbb kialakuló, a személy saját céljain alapuló „végrehajtó” hálózat erôsebb múködésével. Ez lehetôvé teszi, hogy a hipnotizált felnốtt - a gondozóira támaszkodó gyerekhez hasonlóan - átadja a kontrollt a hipnotizôrnek. A hipnózisstílusokkal kapcsolatos vizsgálataink alapján az anyai hipnózis arousalmoduláló, ritmusmódosító, érzelemszabályozó és ingerszelekciós szerepet egyaránt játszhat, míg az apai hipnózisnak inkább az ingerszelekcióban és a ritmus megszabásában lehet szerepe, a baráti hipnózis pedig az önkontroll kialakításához szükséges énerôsítésben segíti a hipnotizáltat (részletesen 1. Bányai, 2008).

Az „anyai” hipnózisoknál a hipnotizőrök testi-fizikai bevonódása feltehetôen elōsegíti a hipnotizált rejtett, belsô világának empátiás átélését. Ennek különösen a korai személyiségfejlôdési zavarok eredményeként kialakuló pszichoszomatikus kórképek pszichoterápiájában lehet jelentôsége: segíthet abban, hogy a hipnotizôr ráérezzen a beteg testi szinten kifejezôdô, verbálisan többnyire meg sem fogalmazható feszültségeire, és segítsen azok mentális feldolgozásában. Ennek idegélettani hátterét az biztosítja, hogy mély hipnózisban az automatikus információfeldolgozás - pl. a zsigeri ingerek feldolgozása - a bal, verbális agyféltekébe tevôdik át, tehát a beteg könnyebben tanulhatja meg, hogyan nevezze nevén testi érzéseit, és hogyan tanulja meg szabályozni azokat (bôvebben: Bányai, 2015). Ilyen módon a hipnózis az érzelmek feldolgozását és kifejezését gátló alexitímiát is enyhítheti (Költő és Bányai, 2015).

Az „apai” hipnózisoknál a hipnotizôr inkább tekintélyére építve vezeti, irányítja a hipnotizáltat. Határozott elképzelései, szándékai vannak, amelyek megvalósítása érdekében kissé korlátozza a hipnotizált önálló kezdeményezéseit. Azok számára, akik vezetésre vágynak, határozottsága biztonságot nyújt. A hipnózis terápiás felhasználása szempontjából fớként az elbizonytalanodott, tanácstalan szorongásos és hangulatzavarokban szenvedô betegek esetében lehet hatékony az „apai” hipnózis stílus.

Az aktív-éber hipnózisok stílusát inkább a „baráti” metaforával jellemezhetjük. Bár a hipnotizôr az adott helyzetben a vezetố szerepét vállalja, tiszteletben tartja a hipnotizált szuverenitását. A két személy egyenrangú, komplementer kapcsolatba kerül egymással. Ez terápiás helyzetben segíthet a betegnek aktivitása, énereje fokozásában, aminek depressziós és szerfüggố betegek gyógyításában lehet szerepe.

\section{INTERAKCIÓS MEGKÖZELÍTÉSÜNK ÉS A HIPNÓZIS SZOCIÁL-PSZICHOBIOLÓGIAI MODELLJÉNEK FOGADTATÁSA}

A nemzetközi szakirodalom azonnal felfigyelt interakciós szemléletû vizsgálataink jelentôségére. Már korai - a szociál-pszichobiológiai modell megfogalmazása elốtti eredményeinket gyakran idézték, és beépítették a terápiás hangsúlyú hipnóziselméletekbe (pl. Brown, 1991). A modell elsố megfogalmazása (Bányai, 1991) után pedig mint a hipnózis legkomplexebb, „talán legátgondoltabb multidimenzionális modelljét” (Hammond, 2005, 132-133.) tartják számon, amely „egyedülálló abban, hogy va- 
lódi reciprok folyamatnak tekinti a hipnózist, és egyidejúleg több dimenzióját vizsgálja” (Lynn és Rhue, 1991, 624.).

A klinikusok - fôként az analitikus szemléletű terapeuták - felismerték laboratóriumi vizsgálataink és a modell terápiás jelentôségét, és eredményeinket felhasználták a terápiás interakciók és a gyógyító kapcsolat értelmezésében (pl. Eisen, 1993; Baker, 2000).

A képalkotó eljárásokkal végzett modern idegtudományos vizsgálatok eredményeit is felhasználva, a szociál-pszichobiológiai modell nyomán Jensen, Adachi, Tomé-Pires, Lee, Osman és Miró (2015) egy olyan „bio-pszichoszociális” modellt javasol, ami erôsebben támaszkodik a mi vizsgálatainkhoz hasonló interakciós kutatásokra. Ezek ugyanis, annak ellenére, hogy a hipnózis gyakorlati alkalmazása szempontjából égetôen szükségesek volnának, egyelôre váratnak magukra. Ennek okát - Kihlstrom (2008) indoklásával egyetértve - abban látom, hogy az ilyen komplex, több tényezôt párhuzamosan vizsgáló kísérletek módszertanilag nagyon nehezen kivitelezhetôek, sok képzett szakembert igényelnek, s ezért ijesztô feladatnak tûnnek. Jól szervezett „csapatmunkával” azonban mégis megvalósíthatóak, és - bár lassabban vezetnek eredményhez, mint az egy-egy tényezôre fókuszáló vizsgálatok - a hipnózis megértése szempontjából nélkülözhetetlenek (Bányai, 2018b).

\section{KÖSZÖNETNYILVÁNÍTÁS}

A szociál-pszichobiológiai modell formálódásában nagy szerepe volt kollégáimnak, elóbb az ELTE Összehasonlító Élettani Tanszék, majd az ELTE Kísérleti Pszichológiai Tanszék, késóbb Affektív Pszichológia Tanszék Hipnóziskutató Laboratóriuma munkatársainak, akikkel a modell alapjául szolgáló, illetve az érvényességét tesztelô kísérleteket csapatmunkában végeztük, és akikkel gondolataimat a munka minden fázisában megvitattam. Bár nevüket a közös publikációk őrzik, külön is köszönetemet fejezem ki Gôsiné Greguss Annának és Varga Katalinnak, akiknek alkotó részvétele nélkül nem születhetett volna meg ez a modell.

Ugyancsak köszönetemet fejezem ki a Magyar Hipnózis Egyesület tagjainak, akik a vizsgálatokban hipnotizórként közremúködtek.

A modell hátterét biztosító kutatást az Országos Tudományos Kutatási Alap 1986-tól több pályázattal támogatta. Az MKM FKFP, a Soros Alapítvány és a Széchényi Profeszszori Ösztöndíj anyagi támogatása is segítséget jelentett a munka elvégzésében.

\section{IRODALOM}

Bandura, A. (1978). The self system in reciprocal determinism. American Psychologist, 33(4), 344-358.

Baker, E. L. (2000). Reflections on the hypnotic relationship: Projective identification, containment, and attunement. International Journal of Clinical and Experimental Hypnosis, 48(1), 56-69.

Bányai, É. I. (1985). A social-psychophysiological approach to the understanding of hypnosis: The interaction between hypnotist and subject. Hypnos. Swedish Journal of Hypnosis in Psychotherapy an Psychosomatic Medicine, 12(4), 186-210. 
Bányai, É. I. (1991). Toward a social-psychobiological model of hypnosis. In J. W. Rhue \& S. J. Lynn (Eds), Theories of hypnosis: Current models and perspectives (pp. 564-598). New York, NY, US: Guilford Press.

Bányai É. I. (1993). A módosult tudatállapotok pszichofiziológiai jellemzői. In Agykutatás és kísérleti pszichológia. Az "Emberi eröforrások fejlesztése" c. világbanki támogatással rendezett önképzési tanfolyam anyaga. (pp. 59-87). Budapest: MTA Pszichológiai Intézete.

Bányai, É. I. (1998). The interactive nature of hypnosis: Research evidence for a social-psychobiological model. Contemporary Hypnosis, 15(1), 52-63.

Bányai É. I. (2000). A hipnózis szociál-pszichobiológiai modellje. Habilitációs dolgozat. Budapest: ELTE.

Bányai, É. (2002). Communication in different styles of hypnosis. In C. A. L. Hoogduin, C. P. D. R. Schaap, \& H. A. A. de Berk (Eds), Issues on hypnosis (pp. 1-20). Nijmegen: Cure and Care Publishers.

Bányai É. (2008). A hipnózis szociál-pszichobiológiai modellje. In Bányai É. \& Benczúr L. (szerk.), A hipnózis és a hipnoterápia alapjai (pp. 379-445). Budapest: ELTE Eötvös Kiadó.

Bányai É. (2015). A hipnózis a kognitív és affektív idegtudomány fényében. In Vértes G. (szerk.), Hipnózis-hipnoterápia (pp. 31-62). Budapest: Medicina Könykiadó.

Bányai, É. I. (2018a). Active-alert hypnosis: History, research and applications. American Journal of Clinical Hypnosis 61(2), 88-107.

Bányai, É. I. (2018b). Researchers in hypnosis meet clinicians: Current issues and future directions. Invited paper presented at a round table discussion. XXI. World Congress of Medical Clinical Hypnosis, Montreal, Canada, August 23-25, 2018.

Bányai, É. I., Gôsi-Greguss, A. C., Vágó, P., Varga, K., \& Horváth, R. (1990). Interactional approach to the understanding of hypnosis: Theoretical background and main findings. In R. Van Dyck, P. Spinhoven, A. J. W. Van der Does, Y. R. Van Rood, \& W. De Moor (Eds), Hypnosis: Current theory, research and practice (pp. 53-69). Amsterdam, The Netherlands: Free University Press.

Bányai, É. I., \& Hilgard, E. R. (1976). A comparison of active-alert hypnotic induction with traditional relaxation induction. Journal of Abnormal Psychology, 85(2), 218-224.

Bányai, É. I., Mészáros, I., \& Csókay, L. (1984). Further data on the psychophysiological factors of the interaction between hypnotist and subject. Paper presented at the 3rd European Congress of Hypnosis in Psychotherapy and Psychosomatic Medicine, Abano Terme - Padova, Italy, May 1984.

Bányai, É. I., Mészáros, I., \& Csókay, L. (1985). Interaction between hypnotist and subject: A social psychophysiological approach. (Preliminary report). In D.Waxman, P. C. Misra, M. Gibson, \& M. A. Basker (Eds), Modern trends in hypnosis (pp. 97-108). New York and London: Plenum Press.

Bányai É., Varga K., \& Gôsiné Greguss A. C. (2001). Szuggesztív egyéniségek: archaikus bevonódás tanárok és hipnotizôrök hatására. In Pléh Cs., László J. \& Oláh A. (szerk.), Tanulás, kezdeményezés, alkotás: Barkóczi Ilona 75. születésnapjára (pp. 313-336). Budapest: ELTE Eötvös Kiadó.

Biró E. (2003). Interakciós szinkronitás az interperszonális adaptációban. Magyar Pszichológiai Szemle, 58(3), 341-362.

Biró E. (2004). A viselkedésben megnyilvánuló interakciós szinkronitás vizsgálatának módszertani problémái. Magyar Pszichológiai Szemle, 59(4), 471-492.

Biró E., \& Bányai É. (2007). Interakciós szinkronitás hipnózisban: megbízható-e az egészleges megítélés? Magyar Pszichológiai Szemle, 62(3), 369-394.

Brown, P. (1991). The hypnotic brain. Hypnotherapy and social communication. New Haven and London: Yale University Press. 
Burleson, B. R. Albrecht, T. L., \& Sarason, I. G. (Eds) (1994). Communication of social support. Thousand Oaks, London: Sage.

Cappella, J. M. (1981). Mutual influence in expressive behavior: Adult-adult and infant-adult dyadic interaction. Psychological Bulletin, 89(1), 101-132.

Chapple, E. D. (1982). Movement and sound: The musical language of body rhythms in interaction. In M. Davis (Ed.), Intaraction rhythms. Periodicity in communicative behavior (pp. 1-51). New York: Human Sciences Press.

Chatrand, T. L., \& Bargh, J. A. (1999). The chameleon effect: The perception-behavior link and social interaction. Journal of Personality and Social Psychology, 76(6), 893-910.

Chertok, L. (1981). Sense and nonsense in psychotherapy: The challenge of hypnosis. London: Pergamon Press.

Condon, W. S. (1982). Cultural microrhythms. In M. Davis (Ed.), Intaraction rhythms. Periodicity in communicative behavior (pp. 53-78). New York: Human Sciences Press.

Copeland, D. R. (1982). Aspects of the hypnotic relationship: A review of psychoanalytic concepts. Paper presented at the Annual Meeting of the American Psychological Association, Washington, D. C.

Csányi V. (1999). Az emberi természet: Humánetológia. Budapest: Vince Kiadó.

Császár N. (2001). A hipnózisra vonatkozó elözetes elvárások szerepének projektív elvü vizsgálata indukált fájdalom kísérleti helyzetben. PhD-disszertáció. Budapest: ELTE.

Diamond, M. J. (1984). It takes two to tango: Some thoughts on the neglected importance of the hypnotist in an interactive hypnotherapeutic relationship. American Journal of Clinical Hypnosis, 27(1), 3-13.

Diamond, M.J. (1987). The interactional basis of hypnotic experience: On the relational dimensions of hypnosis. International Journal of Clinical and Experimental Hypnosis, 35(2), 95-115.

Eisen, M. R. (1993). Psychoanalytic and psychodynamic models of hypnoanalysis. In J. W. Rhue, S. J. Lynn, \& I. Kirsch (Eds), Handbook of Clinical Hypnosis (pp. 123-149). Washington DC: American Psychological Association.

Erickson, M. H., Rossi, E. L., \& Rossi, S. I. (1976). Hypnotic realities. The induction of clinical hypnosis and forms of indirect suggestions. New York, London, Toronto, Sydney: John Wiley.

Ferenczi S. (1909/2000). Indulatáttétel és magábavetítés. In Erôs F. (szerk.), Ferenczi Sándor válogatás (pp. 75-84). Budapest: Új Mandátum Kiadó.

Fourie, D. P. (1983). Width of the hypnotic relationship: An interactional view of hypnotic susceptibility and hypnotic depth. Australian Journal of Clinical and Experimental Hypnosis, 11(1), $1-14$.

Gergely Gy. (2003). A cselekvô én (szelf mint ágens) fogalmának kialakulása csecsemô- és kisgyermekkorban. In Pléh Cs., Kovács Gy., \& Gulyás B. (szerk.), Kognitív idegtudomány (pp. 285-325). Budapest: Osiris Kiadó.

Gergely Gy., \& Watson, J. S. (1996/1998). A szülői érzelmi tükrözés szociális biofeedback modellje: a csecsemó érzelmi öntudatra ébredése és az önkontroll kialakulása. Thalassa, 9(1), 56-105.

Gôsi-Greguss, A. C. (2002). Acoustic analysis of the hypnotist's voice - A preliminary study. In B. Peter, W. Bongartz, D. Revenstorf, \& W. Butollo (Eds), Hypnosis International Monographs Number 6 (pp. 129-136). Munich: MEG Stiftung.

Gốsi-Greguss, A. C., Bányai, É. I., Józsa, E., Suhai-Hodász, G., \& Varga, K. (2004). Hypnosis interaction from an evolutionary perspective: The role of the hypnotist's voice. Paper presented at the $16^{\text {th }}$ International Congress on Hypnosis and Hypnotherapy, October 17-22, 2004. Singapore.

Gốsiné Greguss A. (1996). A hipnotizốr standard hipnózis helyzetben regisztrált verbális kommunikációjának interakciós szempontú elemzése. Bölcsészdoktori disszertáció. Budapest: ELTE.

Gốsiné Greguss A. (2003). Hipnotizôrök affektív prozódiájának vizsgálata. PhD-disszertáció. Budapest: ELTE. 
Grastyán E. (1985). A játék neurobiológiája. Budapest: Akadémiai Kiadó.

Hammond, D. C. (2005). An integrative, multi-factor conceptualization of hypnosis. American Journal of Clinical Hypnosis, 48(2-3), 131-135.

Haley, J. (1958). An interactional explanation of hypnosis. American Journal of Clinical Hypnosis, 28(1), 41-57.

Hatfield, E., Cacioppo, J. T., \& Rapson, R. L. (1994). Emotional contagion. Cambridge: Cambridge University Press.

Heller, K., \& Rock, K. S. (1997). Distinguishing the theoretical functions of social ties: Implications for support interventions. In S. Duck (Ed.), Handbook of personal relationships (pp. 649-670). New York: John Wiley \& Sons.

House, J. S., Landis, K. R., \& Umberson, D. (1988). Social relationships and health. Science, 241(4865), 540-545.

Jensen, M. P., Adachi, T., Tomé-Pires, C., Lee, J., Osman, Z. J., \& Miró, J. (2015). Mechanisms of hypnosis: Toward the development of a biopsychosocial model. International Journal of Clinical and Experimental Hypnosis, 63(1), 34-75.

Kihlstrom, J. F. (2008). The domain of hypnosis, revisited. In M. R. Nash, \& A. Barnier (Eds), Oxford handbook of hypnosis (pp. 21-52). Oxford: Oxford University Press.

Költố A., \& Bányai É. (2015). Az alexitímia és a hipnotikus fogékonyság összefüggése - szakirodalmi áttekintés. Mentálhigiéné és Pszichoszomatika, 16(1), 1-33.

Kraemer, G. W. (1992). A psychobiological theory of attachment. Behavioral and Brain Sciences, 15(3), 493-511.

Lynn, S. J., Nash, M., Rhue, J. W., Carlson, V., Sweeney, C., Frauman, D., \& Givens, D. (1985). Non-volition and hypnosis. In D.Waxman, P. C. Misra, M. Gibson, \& M. A. Basker (Eds), Modern trends in hypnosis (pp. 109-117). New York and London: Plenum Press.

Lynn, S. J., \& Rhue, J. W. (1991). Hypnosis theories: Themes, variations, and research directions. In S. J Lynn, \& J. W. Rhue (Eds), Theories of hypnosis: Current models and perspectives (pp. 601-626). New York, London: Guilford Press.

Nash, M. R., \& Spinler, D. (1989). Hypnosis and transference: A measure of archaic involvement. International Journal of Clinical and Experimental Hypnosis, 37(2), 129-144.

Posner, M. I., \& Rothbart, M. K. (2011). Brain states and hypnosis research. Consciousness and Cognition, 20(2), 325-327.

Pusztai, F. S. (2017). Hypnosis styles in active-alert hypnosis. MA Thesis. Budapest, Hungary: ELTE.

Sarason, B. R., Sarason, I. G., \& Gurong, R. A. R. (1997). Close personal relationships and health outcome. In S. Duck (Ed.), Handbook of personal relationships (pp. 547-573). New York: John Wiley \& Sons.

Sheehan, P. W., \& McConkey, K. M. (1982). Hypnosis and experience: The exploration of phenomena and process. Hillsdale, NJ: Erlbaum.

Shor, R. E. (1962/2008). A hipnózis mélységének három dimenziója. In Bányai É., \& Benczúr L. (szerk.), A hipnózis és a hipnoterápia alapjai (pp. 203-216). Budapest: ELTE Eötvös Kiadó.

Shor, R. E. (1979). A phenomenological method for the measurement of variables important to an understanding of the nature of hypnosis. In E. Fromm, \& R. E. Shor (Eds), Hypnosis: Developments in research and new perspectives (2nd ed) (pp. 105-135). New York, USA: Aldine.

Stern, D. N. (1985). The interpersonal world of the infant. New York: Basic Books.

Stern, D. N. (1999) The vitality contours: The temporal contour of feelings as a basic unit for constructing the infant's social experience. In P. Rochat (Ed.), Early social cognition. Understanding others in the first year of life (pp. 67-80). London: Lawrence Erlbaum Associates.

Szekely, A., Kovacs-Nagy, R., Bányai, É. I., Gôsi-Greguss, A. C., Varga, K., Halmai, Z., Ronai, Z., \& Sasvari-Szekely, M. (2010). Association between hypnotizability and the Catechol-O-Methylt- 
ransferase (COMT) polymorphism. International Journal of Clinical and Experimental Hypnosis, 58(3), 301-315.

Tickle-Degnen, L., \& Rosenthal, R. (1990). The nature of rapport and and its nonverbal correlates. Psychological Inquiry, 1(4), 285-294.

Tickle-Degnen, L., \& Rosenthal, R. (1992). Nonverbal aspects of therapeutic rapport. In R. S. Feldman (Ed.), Application of nonverbal behavioral theory and research (pp. 143-164). Hillsdale, NJ: Erlbaum.

Vaitl, D., Birbaumer, N., Gruzelier, J., Jamieson, G. A., Kotchoubey, B., Kübler, A., \& Pütz, P. (2005). Psychobiology of altered states of consciousness. Psychological Bulletin, 131(1), 98-127.

Varga K. (2017). A hipnotikus kapcsolat élményvilága. Budapest: Medicina Kiadó.

Varga, K., Bányai, É. I., \& Gôsi-Greguss, A. C. (1994). Parallel application of the experiential analysis technique with subject and hypnotist: A new possibility for measuring interactional synchrony. International Journal of Clinical and Experimental Hypnosis, 42(2), 130-139.

Varga K., Bányai É., \& Gốsiné Greguss A. (2004). A hipnotizôr a hipnotikus interakcióban: a szubjektív élmények elemzése. Pszichoterápia, 13(3), 140-147.

Varga, K., Bányai E., Gôsi-Greguss A., \& Tauszik K. (2013). Phenomenological aspects of hypnotic interactions: The effect of kinship. International Journal of Clinical and Experimental Hypnosis, 61(4), 401-415.

Varga, K., Bányai, É. I., Józsa, E., \& Gôsi-Greguss, A. C. (2008). Interactional phenomenology of maternal and paternal hypnosis styles. Contemporary Hypnosis, 25(1), 14-28.

Varga, K., Józsa E., Bányai, É. I., \& Gôsi-Greguss, A. C. (2006). A new way of characterizing hypnotic interactions: Dyadic Interactional Harmony (DIH) questionnaire. Contemporary Hypnosis, 23(4), 151-166.

Varga, K., Józsa, E., \& Kekecs, Z. (2014). Comparative analysis of phenomenological patterns of hypnotists and subjects: An interactional perspective. Psychology of Consciousness: Theory, Research, and Practice, 1(3), 308-319.

Varga, K., \& Kekecs, Z. (2014). Oxytocin and cortisol in the hypnotic interaction. International Journal of Clinical and Experimental Hypnosis, 62(1), 111-128.

Varga, K., \& Kekecs, Z. (2015). Feature-based coding system: A new way of characterizing hypnosis styles. International Journal of Clinical and Experimental Hypnosis, 63(2), 215-235.

Von Bertalanffy, L. (1976). General System theory: Foundations, development, applications (Revised edition). New York: George Braziller.

Whitehead, S., Noller, P., \& Sheehan, P. W. (2008). The hypnotist in the hypnosis interaction: The impact of first impressions on perceptions of hypnotizability. International Journal of Clinical and Experimental Hypnosis, 56(4), 394-424. 


\title{
HYPNOSIS RESEARCH WITH AN INTERACTIONAL PERSPECTIVE: \\ THE EXPERIMENTAL BACKGROUND OF THE SOCIAL-PSYCHOBIOLOGICAL MODEL OF HYPNOSIS
}

\author{
BÁNYAI, ÉVA
}

\begin{abstract}
After summarizing the theoretical considerations standing in the background of the approach of hypnosis from an interactional perspective, the paper describes the complex, multidimensional experimental paradigm our research team has been using since 1982. We have been studying the physiological, behavioral, subjective experiential, and relational characteristics of both participants (hypnotist and subject) of the hypnosis interaction simultaneously, and analyze the interrelationship of these factors that play an important role in the development of hypnosis. After describing the most important findings of our studies, the paper summarizes the social-psychobiological model of hypnosis based on our findings, then outlines the model's practical relevance to therapy and recount its international reception.
\end{abstract}

Keywords: hypnosis, interactional approach, social-psychobiological model, interaction synchrony, hypnosis style

A cikk a Creative Commons Attribution 4.0 International License (https:// creativecommons.org/licenses/by/4.0) feltételei szerint publikált Open Access közlemény, melynek szellemében a cikk bármilyen médiumban szabadon felhasználható, megosztható és újraközölhetô, feltéve, hogy az eredeti szerzô és a közlés helye, illetve a CC License linkje és az esetlegesen végrehajtott módosítások feltüntetésre kerülnek. (SID_1) 